\title{
DOPED NANOCRYSTALLINE CALCIUM CARBONATE-PHOSPHATE - A BIOMATERIAL FOR BONE REPAIR AND STRENGTHEINING BY DRUG DELIVERY
}

\author{
L. F. Koroleva ${ }^{1}$, M. N. Dobrinskaya ${ }^{2}$, I. S. Kamantsev ${ }^{1}$ \\ ${ }^{1}$ Institute of Engineering Science, Ural Branch of the Russian Academy of Sciences, 34 Komsomolskaya st., \\ Ekaterinburg, Russian Federation \\ ${ }^{2}$ Ural State Medical University, 3 Repina st., Ekaterinburg, Russian Federation \\ *Corresponding author. E-mail: lq@imach.uran.ru; address for correspondence: 34, ul. Komsomolskaya, \\ 620049, Ekaterinburg, Russian Federation. Tel.: +7 343 3741853; fax: +7 3433745330
}

It is demonstrated that doped nanocrystalline calcium carbonate-phosphate is a biocompatible material that influences actively the osteogenesis bone repair in fractures, strengthening of bone tissues for drug delivery regardless of age. The introduction of doped nanocrystalline calcium carbonate-phosphates into animals increases 5 times the mechanical strength of the bone tissue. The most durable bone may occur when doped silicon, iron and magnesium nanocrystalline calcium carbonate-phosphate is introduced into an animal. The results obtained indicate the possibility of producing bioceramics based on doped nanocrystalline calcium carbonate-phosphates.

Keywords: doped calcium carbonate-phosphate; bone repair; strengthening; drug delivery.

DOI: $10.17804 / 2410-9908.2015 .5 .147-157$

\section{Introduction}

The problems of modern medicine and biotechnology involve not only the creation of implants for replacing bone tissues, but also the synthesis of biologically active materials promoting the fullest restoration of tissues. Materials that enhance bone regeneration have a wealth of potential clinical applications from the treatment of nonunion fractures to spinal fusion.

While materials intended for implantation were designed to be 'bio-inert', new materials have now shifted toward the design of deliberately 'bioactive' materials that integrate with biological molecules or cells and regenerate tissues. In the case of bone, materials should preferably be both osteoinductive (capable of promoting the differentiation of progenitor cells down an osteoblastic lineage), osteoconductive (support bone growth and encourage the ingrowth of surrounding bone), and capable of osseointegration (integrate into surrounding bone). The ideal basic premise, if following the tissue engineering paradigm, is that the materials will be resorbed and replaced over time by, and in tune with, the body's own newly regenerated biological tissue.

It is known that after 55 years of age the majority of the mankind suffer from various diseases of joints, lower strength of bone tissue, osteochondrosis, osteoporosis and frequent fractures. The development of a biomaterial with highly active resorption and transdermal ability to activate the processes of osteogenesis in humans of all ages for the restoration of bone tissue and for strengthening tooth tissue is an actual problem. Hydroxyapatite has been commonly used as a bone graft substitute in various kinds of clinical fields. The synthesis of nanocrystalline calcium hydroxyapatites for the fabrication of composite materials as bone graft substitutes is a critical issue in bioceramic research all over the world [1-20].

Therefore it is necessary to create a material based on inorganic calcium phosphates, which are easily assimilated, and not only through the gastrointestinal tract. Doped nanocrystalline calcium carbonate-phosphate is a biocompatible material that has an active effect on osteogenesis, including activity through the skin, on the strengthening of bone and dental tissues [21-26].

The bone tissue should be characterized as an organic matrix impregnated by amorphous $\mathrm{Ca}_{3}\left(\mathrm{PO}_{4}\right)_{2}$ and crystals of calcium hydroxyapatite synthesized in bone tissue osteoblast cells. The solid residual of the bone tissue contains $70 \%$ of calcium hydroxyapatite $\mathrm{Ca}_{10}\left(\mathrm{PO}_{4}\right)_{6}(\mathrm{OH})_{2}$ and

Koroleva L.F. et al. / Doped nanocrystalline calcium carbonate-phosphate - a biomaterial for bone re- 
$30 \%$ of an organic component, namely, collagen fiber. Ions $\mathrm{Na}^{+}, \mathrm{K}^{+}, \mathrm{Mg}^{2+}, \mathrm{Fe}^{2+}, \mathrm{Cl}^{-}$and $\mathrm{CO}_{3}{ }^{2-}$ are contained in the structure of calcium hydroxyapatite of the bone tissue besides $\mathrm{Ca}^{2+}$ and $\mathrm{PO}_{4}{ }^{3-}$. The content of anions $\mathrm{CO}_{3}{ }^{2-}$ in the calcium hydroxyapatite of the bone material can amount up to 8 wt. $\%$, and they substitute hydroxyl or phosphate groups. Therefore, in view of the carbonate groups introduced into the structure of calcium hydroxide phosphate, its probable formula will be as follows $[2,10,27,28-31]: \mathrm{Ca}_{10}\left(\mathrm{PO}_{4}\right)_{6}\left(\mathrm{CO}_{3}\right)_{\mathrm{x}}(\mathrm{OH})_{2-\mathrm{x}}$.

The crystal structure of calcium hydroxyapatite was discussed in [10], where a type of the elemental cell of crystal hydroxyapatite was presented. The model of the calcium hydroxyapatite crystal structure has the space group P63/m $(a=b=9.432 \AA$ and $c=6.881 \AA)$.

Hydroxyapatite crystals have a hexagonal lattice, which contains two types of cationic positions of $\mathrm{CaI}(001)$ and $\mathrm{CaII}(002)$ corresponding to the polyhedrons $\mathrm{CaO}_{9}$ and $\mathrm{CaO}_{7}$ respectively. The vacancies can be filled with bivalent cations of the trace elements of a living organism and with anions $\mathrm{SiO}_{2 \mathrm{x}}{ }^{2-}, \mathrm{SO}_{2 \mathrm{x}}{ }^{2-}, \mathrm{Cl}^{-}$and $\mathrm{F}^{-}$.

The synthesis of nanocrystalline calcium carbonate-phosphates doped with microelements and having a transdermal effect was performed by the creation of ammonium calcium hydroxycarbonate containing different doping cations of microelements which are specific for living tissue and which enter the calcium channels of the crystal structure. The biomaterial based on doped nanocrystalline calcium carbonate-phosphates has a high degree of resorption; it is used to activate osteogenesis in a human organism of any age in order to both restore and strengthen bone tissues, as well as to strengthen tooth tissue [21-26].

Previously, we have discussed the mechanism of synthesizing doped nanocrystalline calcium carbonate-phosphate and a model for describing the kinetics of the system, which is oscillatory in nature and can be represented as a brusselator of the simplest implementation of cubic nonlinearity [25].

This work deals with the effect of nanocrystalline calcium carbonate-phosphate doped with cations of iron, magnesium, potassium, zinc, lithium, manganese, copper, gold, silicon, which is intended for bone repair by drug delivery; it also studies the strengthening of bone tissue and the strength of ceramics to be used for implants.

\section{Experimental procedure}

\subsection{Bone repair}

The following samples were used in the experiment. Basic substances obtained by oscillating reactions are $\mathrm{CaHPO}_{4} \cdot 2 \mathrm{H}_{2} \mathrm{O}$ or $\mathrm{Ca}_{8} \mathrm{H}_{2}\left(\mathrm{PO}_{4}\right)_{6} \cdot 5 \mathrm{H}_{2} \mathrm{O}$ crystals, and additionally $\mathrm{Ca}_{9,70} \mathrm{P}_{6,04} \mathrm{O}_{23,{ }_{2} 6} \mathrm{Cl}_{2,35}(\mathrm{OH})_{2,01}$ or $\mathrm{Ca}_{4,905}\left(\mathrm{PO}_{4}\right)_{3,014} \mathrm{Cl}_{0,595}(\mathrm{OH})_{1,67}$, sometimes $\mathrm{Ca}_{5}\left(\mathrm{PO}_{4}\right)_{3} \mathrm{OH}$. There remains a small amount of the $\mathrm{CaCO} 3$ phase (calcite or aragonite). The crystal structure of the compounds has two types of channels with different positions of calcium cations, such as $\mathrm{Fe}^{2+}, \mathrm{Mg}^{2}$, $\mathrm{Zn}^{2+}, \mathrm{K}^{+}, \mathrm{Si}^{4+}, \mathrm{Mn}^{2+}, \mathrm{Cu}^{2+}, \mathrm{Li}^{+1}, \mathrm{Au}^{3+}$.

For synthesizing samples of doped calcium carbonate-phosphate, calcium carbonate of three crystal structures was used. They are calcite (rhombohedral), vaterite (hexagonal) and aragonite (orthorhombic). Calcium carbonate-phosphate was precipitated by o-phosphoric acid ( $2 \mathrm{~mol} / \mathrm{l})$, which was added dropwise into a calcium carbonate suspension in an ammonium chloride solution (2 $\mathrm{mol} / \mathrm{l}$ ) at 45 to $55^{\circ} \mathrm{C}$. The size of the $\mathrm{pH}$ environment varied between 5.2 and 6.5 depending on the molar ratio $\mathrm{Ca} / \mathrm{P}$ (1.55 to 1.67). Doping cations were added during calcium carbonate precipitation. The choice of the doping cations is caused by the concentration ratios of the above-mentioned elements in the bone tissue. The precipitate of synthesized calcium carbonate-phosphates was separated by filtering, washed by water and dried at temperatures not higher than $75{ }^{\circ} \mathrm{C}$.

In addition, in process of synthesis possible introduction of cations $\mathrm{NH}_{4}{ }^{+}$were observed $[21-23,25]$. The formation of calcium phosphate chloride hydroxide bonds is according to the following scheme:

Koroleva L.F. et al. / Doped nanocrystalline calcium carbonate-phosphate - a biomaterial for bone repair and strengtheining by drug delivery 


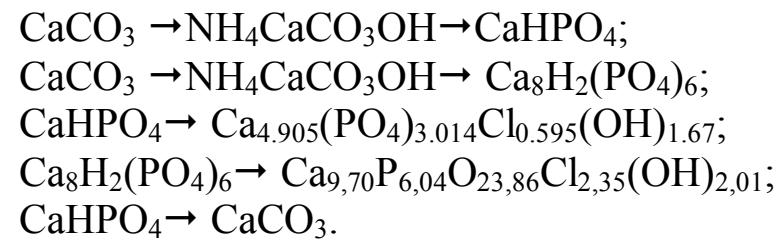

Or in general view:

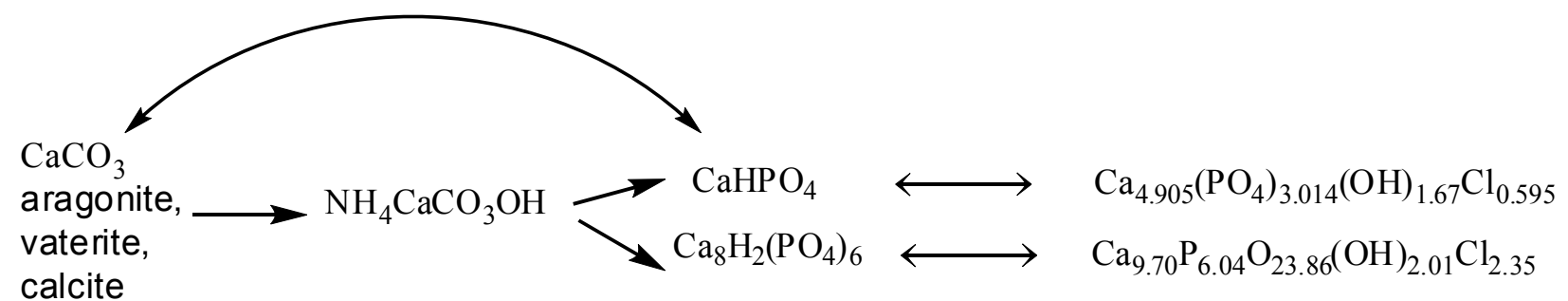

The whole system has an oscillating character, and it can be presented as a brusselator of the simplest implementation of cubic nonlinearity by the following chemical reaction: $2 \mathrm{X}+\mathrm{Y} \rightarrow 3 \mathrm{X}$ $[25]$.

The particle size analysis data indicate that our samples contain nanoparticles ranging in size down to $10 \mathrm{~nm}$, at a level of $4.5 \%$. In the doped calcium carbonate-phosphate samples, most of the particles, which are aggregated, fall in the size range 5 to $20 \mu \mathrm{m}$. (The particle size analysis was performed by centrifugal sedimentation with Shimadzu SA-CP2.)

It is believed that a medication for drug delivery is extremely promising. Molecules introduced for drug delivery must be neutral, because they can be hindered by the hydrophobic corneous layer. The substance must have sufficient solubility in the corneous layer of hydrophilic particles and corium. In addition, the molecule must have a small size (approximately 500 Dalton). Of particular interest is a substance with transdermal activity, used to restore the bone. Over the past 10 years hundreds of thousands of people have suffered from injuries and other pathologies, such as degeneration of the musculoskeletal system. Over the decade a combat with the diseases of bone and joints has been announced by the World Health Organization, but the problem still remains relevant.

The study used a powder of doped nanocrystalline calcium carbonate-phosphate for treatment of the fracture of the radial bone of a human limb (64 years old), which is rubbed into skin. Figure 1a shows the course of the fracture and the transportation of doped nanocrystalline calcium carbonate-phosphate to the fracture within the first hours (shown by an arrow).

Figure $1 b$ demonstrates the state after 2 weeks. The boundary of the concentration of doped nanocrystalline calcium carbonate-phosphate is clearly visible. After four weeks there is complete bone knitting with the formation of a callus turning into osteoid tissue. The study involved 10 people of various ages, and all bones knitted well within a month, regardless of age.

In the control group aged over 60 the formation of callus occurs within 5 or 6 weeks.

The interaction of doped nanocrystalline calcium carbonate-phosphates with membrane cells was also shown in $[24,32]$. The phenomenon of microelement migration with doped nanocrystalline calcium carbonate-phosphates may be used in the development of transdermal drug delivery. The absorption of the doped nanocrystalline calcium carbonate-phosphate powder by skin, i.e., the corneous layer is observed immediately after a light massage. This fact suggests that nanoparticles of doped nanocrystalline calcium carbonate-phosphate have sufficient solubility in the hydrophobic corneous and hydrophilic layers of the dermis. It is logical to assume that the next stage is dissociation of doped calcium carbonate-phosphates to form cations and anions, which are then transported through the cell membrane, see [24]. 
The ion exchange phenomena occurring with calcium carbonate-phosphate bioceramics are associated with reactivity towards bone bonding, i. e., the formation of a mineralized interfacial layer between bioceramics and bone tissue, which insures their cohesion.

Figure 2 shows XRD patterns of doped nanocrystalline calcium carbonate-phosphate, which is rubbed into skin to treat bone fracture. The doping elements are $\mathrm{Mg}(0.74 \mathrm{wt} \%), \mathrm{Zn}(0.05 \mathrm{wt} . \%)$, $\mathrm{Fe}\left(0.08\right.$ wt.\%), $\mathrm{Au}\left(0.002\right.$ wt.\%). The samples contain $\mathrm{CaHPO}_{4} \cdot 2 \mathrm{H}_{2} \mathrm{O} 59 \%$ and $\mathrm{Ca}_{5}\left(\mathrm{PO}_{4}\right)_{3} \mathrm{OH}$ $15 \%$.

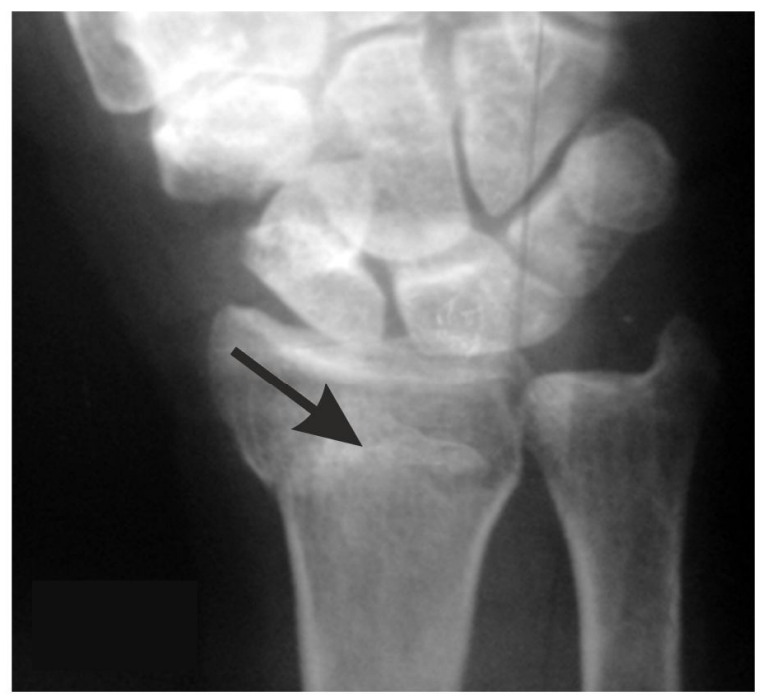

$a$

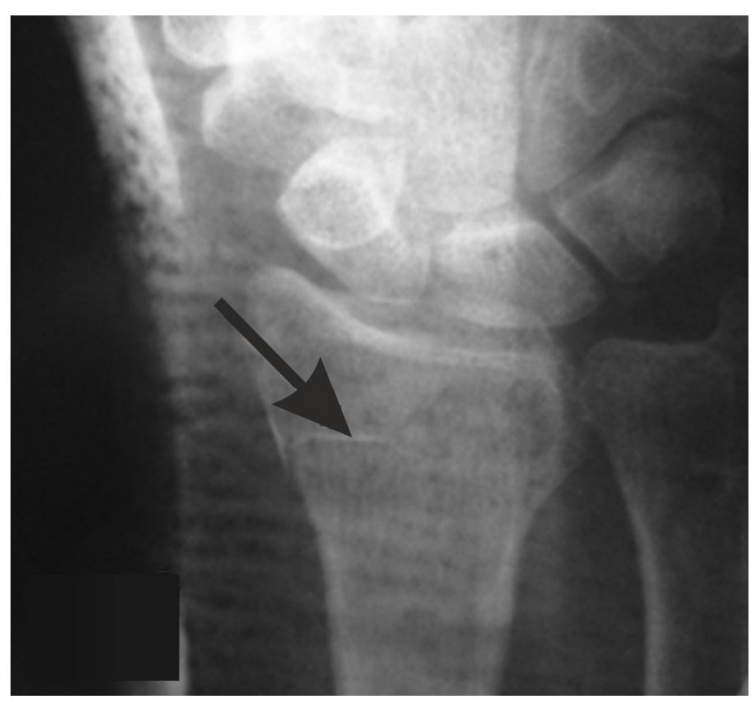

$b$

Fig. 1. Roentgenograms of the radial bone of a human limb:

$a$ - the course of fracture and transportation of doped nanocrystalline calcium carbonate-phosphate to the fracture within the first hours (shown by an arrow); $b$ - the state after 2 weeks.

Table 1 shows the chemical composition of the samples of doped calcium carbonatephosphates used in the experiment.

Table 1 - The chemical composition of the samples of doped calcium carbonate-phosphates

\begin{tabular}{|l|l|l|l|l|l|l|l|}
\hline \multirow{2}{*}{ Samples } & \multicolumn{7}{|c|}{ The chemical composition of the samples, wt. \% } \\
\cline { 2 - 9 } & $\mathrm{Ca}$ & $\mathrm{P}$ & $\mathrm{Mg}$ & $\mathrm{Fe}$ & $\mathrm{Zn}$ & $\mathrm{Au}$ & $\mathrm{NH}_{4}$ \\
\hline 1 & 34.05 & 14.28 & 0.37 & 0.14 & 0.05 & 0.002 & 0.33 \\
\hline 2 & 33.30 & 16.50 & 0.74 & 0.06 & 0.05 & 0.002 & 0.32 \\
\hline 3 & 29.7 & 15.7 & 0.70 & 0.14 & 0.04 & 0.0008 & 0.31 \\
\hline
\end{tabular}

Figure 2 shows XRD patterns of doped nanocrystalline calcium carbonate-phosphate, which is rubbed into skin to treat bone fracture. The doping elements are $\mathrm{Mg}(0.74 \mathrm{wt} . \%)$, $\mathrm{Zn}\left(0.05\right.$ wt. \%), $\mathrm{Fe}\left(0.08\right.$ wt. \%), $\mathrm{Au}\left(0.002\right.$ wt. \%). The samples contain $\mathrm{CaHPO}_{4} \cdot 2 \mathrm{H}_{2} \mathrm{O} 59 \%$ and $\mathrm{Ca}_{5}\left(\mathrm{PO}_{4}\right)_{3} \mathrm{OH} 15 \%$. 


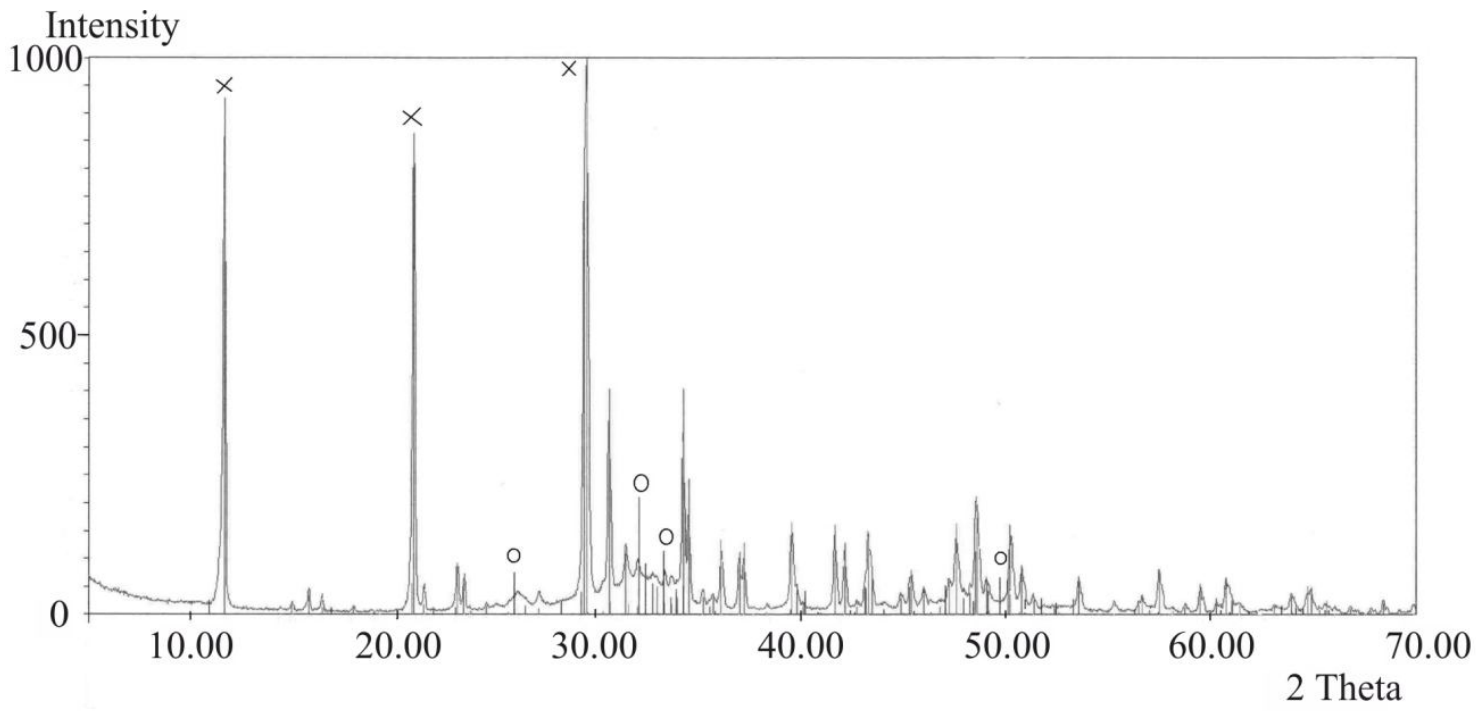

Fig. 2. XRD patterns of iron, magnesium, zinc, gold calcium carbonate-phosphate doped with: $\mathrm{x}$ - diffraction lines of $\mathrm{CaHPO}_{4} \cdot 2 \mathrm{H}_{2} \mathrm{O}, \mathrm{o}$ - diffraction lines of $\mathrm{Ca}_{5}\left(\mathrm{PO}_{4}\right)_{3} \mathrm{OH}$

\subsection{Bone strengthening}

Experiments were carried out on white Wistar rats and Chinchilla rabbits. A $10 \%$ aqueous suspension of doped nanocrystalline calcium carbonate-phosphate and powders was used in the research. The suspension of calcium carbonate phosphates was introduced into the animals through an enteral tube in amounts of $5 \mathrm{ml}$ within 40 days, $30 \mathrm{mg}$ per $1 \mathrm{~kg}$ of live weight (there were four groups of ten animals, namely, I - placebo, II - sample 1, III - sample 2, IV -sample 3). Table 2 shows the chemical composition of the samples used in this experiment.

A Testometric M500-100AT universal testing machine (100 KN maximum load, embedded computer) was used in the experiment.

Table 2 - Chemical composition of the samples of calcium carbonate-phosphate

\begin{tabular}{|c|l|l|l|l|l|l|l|l|}
\hline \multirow{2}{*}{ sample } & \multicolumn{9}{|c|}{ Chemical composition } \\
\cline { 2 - 9 } & Ca, wt. \% & P, wt. \% & Mg, mol. \% & Fe, mol. \% & K, mol. \% & Li, mol. \% & Zn, mol. \% & SiO $_{2}$ \\
\hline 1 & $33-35$ & $16-17$ & 0.005 & 0.001 & $0.002-0.003$ & 0.003 & & \\
\hline 2 & $33-35$ & $16-17$ & 0.005 & 0.002 & $0.002-0.03$ & & 0.02 & \\
\hline 3 & $33-35$ & $16-17$ & 0.004 & 0.001 & & & & 0.002 \\
\hline
\end{tabular}

Figure 3 presents a diagram of tensile strength for the destruction of bone tissue (crus) depending on the samples of doped calcium carbonate-phosphates used for introduction into the animals.

The most durable bone may occur when sample 3 is introduced into an animal, that is, with the addition of silicon, iron and magnesium. Thus, the mechanical fracture strength of bone tissue increases almost 5 times. 


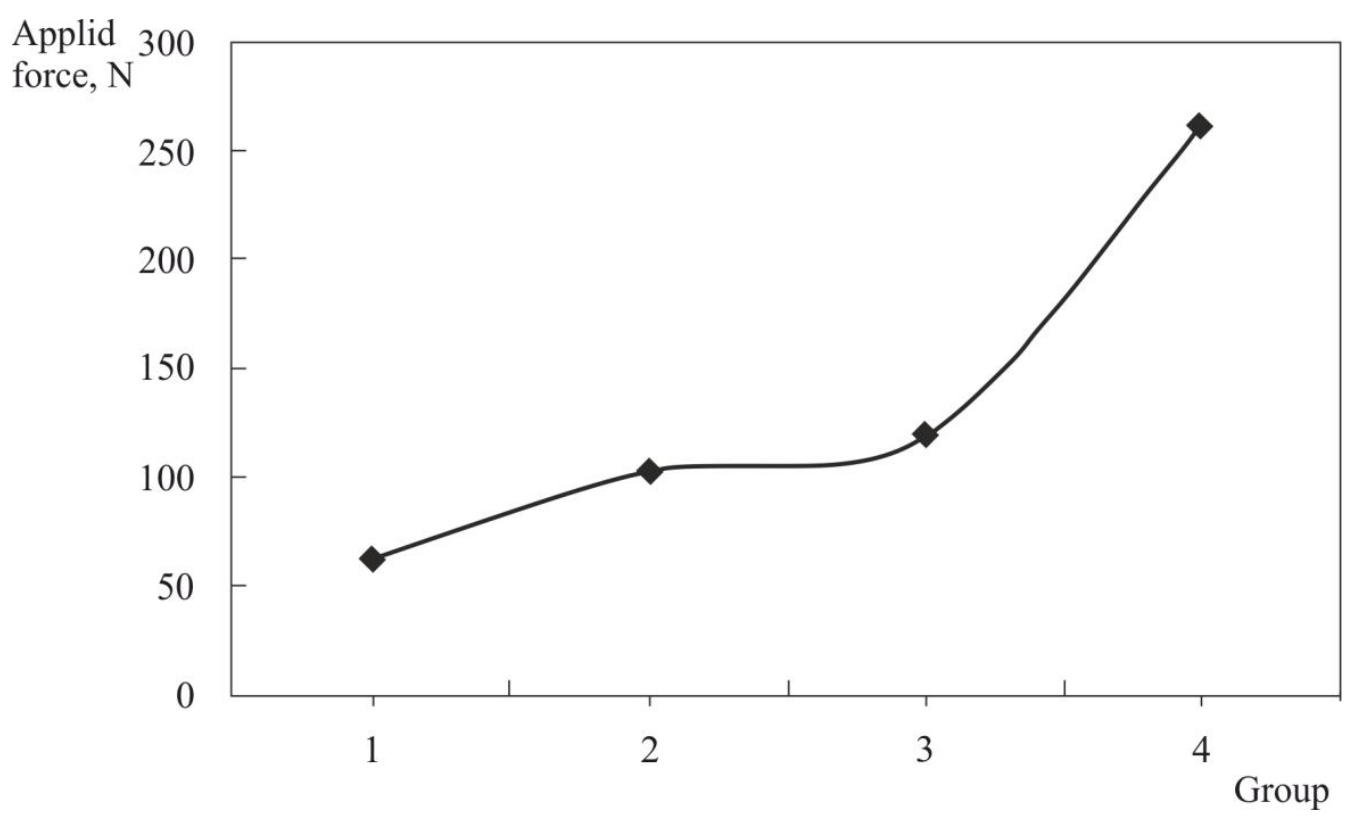

Fig. 3. Mechanical fracture strength of bone tissue depending on the samples of doped calcium carbonate-phosphates used for the introduction into animals: point 1 on the $\mathrm{x}$-axis is placebo, point 2 -sample 1 , point 3 - sample 2 , point 4 - sample 3

\subsection{Ceramics strength}

As shown in [33], silicon has an effect on the differentiation, proliferation and osteoblast collagen synthesis, and affects the remodeling and development of osteoclasts and their absorption. Silicon is essential for the synthesis of collagen and glycosaminoglycans that form a basis for the matrix of bone and cartilage. It also takes part in bone mineralization. It plays a significant role in restoring bone tissue. Bone fracture causes a 50 -fold increase of silicon content in the bones of the body as compared to the normal state. Once the bones are fused, the silicon level comes back to normal. We know that silicon present in hydroxyapatite-based biocompatible ceramics in a concentration of 0.4 to 1.4 per cent participates in the osteogenesis process in a living organism. The content of silicon in dental tissues is 0.8 to $0.9 \%$.

When ceramics based on doped calcium carbonate-phosphates are obtained, silicon oxide is added in the quantity of 5 to $15 \%$. The samples of doped calcium carbonate-phosphates were well compacted under a pressure of $200 \mathrm{~kg} / \mathrm{cm}^{2}$. The mechanical strength of the samples was studied. Figure $4 a$ presents a diagram of mechanical bending strength $\sigma_{\mathrm{bB}}$ as depending on the concentrations of $\mathrm{SiO}_{2}$ in the powder of doped calcium carbonate-phosphates (test point scheme, Fig. $4 \mathrm{~b}$ ). 

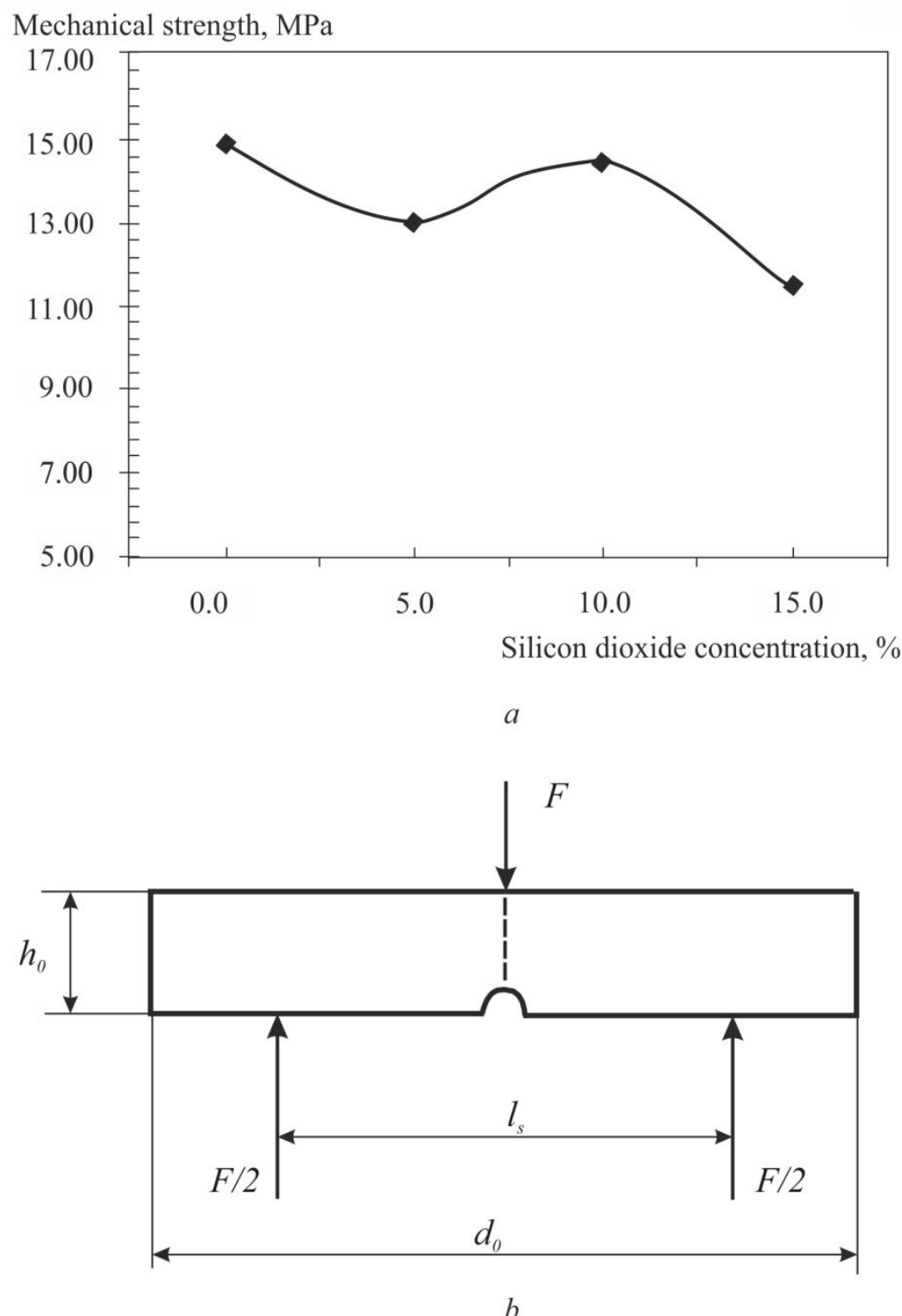

Fig. 4. Mechanical bending strength of biocompatible ceramics (a), test point scheme $(b)$, $F$ - applied force sistance.

Bending strength is determined by the formula $\sigma_{\mathrm{bB}}=\mathrm{F} \cdot 1_{\mathrm{s}} / 4 \omega$, where $\omega$ is the moment of re-

The obtained samples of ceramics based on calcium carbonate-phosphate doped with iron, magnesium, zinc and gold are less durable, and they cannot withstand an applied force of than 3 to $5 \mathrm{MPa}$. Figure 5 a shows samples of ceramics based on calcium carbonate-phosphate doped with iron, magnesium, zinc and gold. For example, the compressive strength of the samples of ceramics ranges to $7 \mathrm{MPa}$.

Three-point bending tests. The diameter of the sample was $6 \mathrm{~mm}$; the distance between the supports was $30 \mathrm{~mm}$ and the loading speed was $0.25 \mathrm{~mm} / \mathrm{min}$. A test on three-point bending and compression was performed on a Zwick/Roell Z 2.5 universal testing machine. The compression tests were conducted on smooth strikers. The samples were used in the form of a parallelepiped with a height of $8.8 \mathrm{~mm}$ and a cross-section of $30.5 \mathrm{~mm}$. The loading diagram is given in Fig. $5 \mathrm{~b}$. 

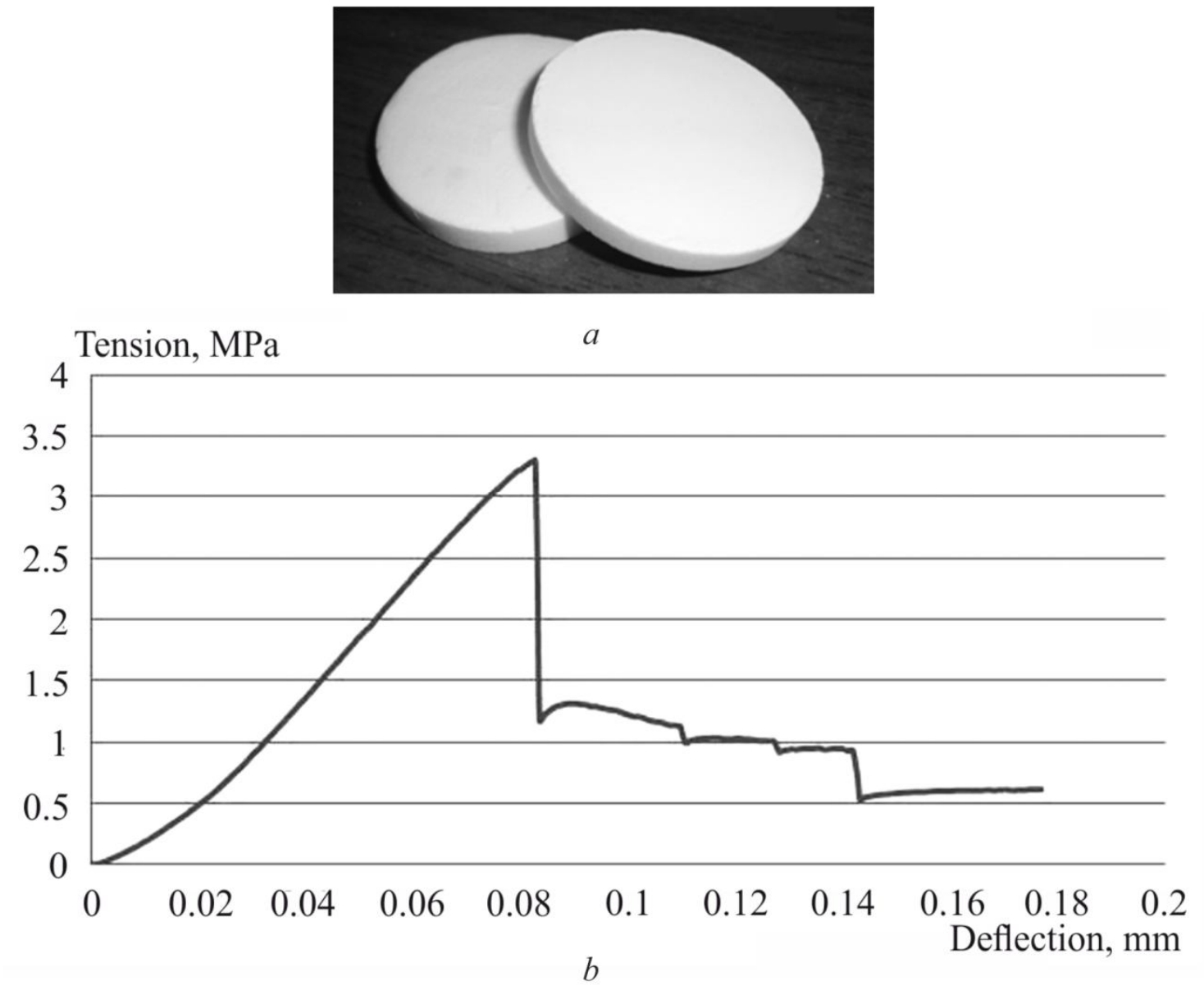

Fig. 5. The samples of ceramics based on calcium carbonate-phosphate doped with iron, magnesium, zinc, gold $(a)$; the loading diagram $(b)$

The experimental data shows a possibility of the production of active bioceramics based on calcium hydroxyapatite. These bioceramics are remarkable for the presence of cation vacancies in the crystal structure. The heat treatment of the samples based on doped calcium carbonatephosphates at temperatures ranging between 900 and $1100{ }^{\circ} \mathrm{C}$ results in the formation of calcium hydroxyapatite ( $99 \%$ ) with calcium channels, as evidenced by the X-ray and chemical analyses.

This fact can be explained by the presence of free channels in the crystal structure after the heat treatment process. The general formula can be represented with cation vacancies as $\mathrm{Ca}_{10-\mathrm{x}-}$ ${ }_{\mathrm{u}} \mathrm{V}_{\mathrm{u}}\left(\mathrm{PO}_{4}\right)_{6-\mathrm{y}}(\mathrm{OH})_{4+\mathrm{z}}$, where $\mathrm{x}=0.131 ; \mathrm{y}=0.414 ; \mathrm{u}=1.028 ; \mathrm{z}=0.006, \mathrm{~V}_{\mathrm{u}}$ is a cation vacancy. The cation vacancies in the structure, which was formed by the removal of ammonium cations, activate the interaction of calcium hydroxyapatite with amine groups of proteins in living organisms.

\section{Conclusion}

Doped nanocrystalline calcium carbonate-phosphate extends significantly the functionality for drug delivery: it can be used to speed up the processes of bone repair and bone tissue strengthening. The advantage over other calcium phosphate biomaterials is strengthening of bone and tooth tissues of a human being of any age, the substances being transported through skin to restore broken bones in a critically short period of time regardless of age. The mechanical fracture strength of bone tissue increases almost 5 times with the introduction of nanocrystalline doped calcium carbonate-phosphate in the body. The most durable bone may occur when doped silicon, iron and magnesium nanocrystalline calcium carbonate-phosphate is introduced into an animal. Thus, the mechanical fracture strength of bone tissue increases almost 5 times. The biomaterial based on

Koroleva L.F. et al. / Doped nanocrystalline calcium carbonate-phosphate - a biomaterial for bone re- 
nanocrystalline calcium carbonate-phosphates doped with $\mathrm{Fe}^{2+}, \mathrm{Mg}^{2+}, \mathrm{Zn}^{2+} \mathrm{K}^{+}, \mathrm{Si}^{4+}, \mathrm{Au}$ can be considered a new-generation medicinal substance by drug delivery.

\section{Acknowledgement}

The equipment installed in the Center of Collective Use (CCU) of the Institute of Engineering Science, Russian Academy of Sciences (Ural Branch), was used in the experiment.

The research was funded by the Russian Foundation for Basic Research - Urals, project No 07-03-96076-[r].

\section{References}

1. Bouyer E., Gitzhofer F., Boulos M. I. Morphological study of hydroxyapatite nanocrystal suspension // Journal of Materials Science: Materials in Medicine. - 2000. - Vol. 11, no. 8. P. 523-531. - DOI: 10.1023/A:1008918110156.

2. Champion E. Sintering of calcium phosphate bioceramics // Acta Biomaterialia. - 2013. Vol. 9, iss. 4. - P. 5855-5875. - DOI: 10.1016/j.actbio.2012.11.029.

3. Samar J. Kalita, Abhilasha Bhardwaj, Himesh A. Bhatt. Nanocrystalline calcium phosphate ceramics in biomedical engineering // Materials Science and Engineering: C. - 2007. - Vol. 27, iss. 3. - P. 441-449. - DOI: 10.1016/j.msec.2006.05.018.

4. Hong Li, Min Ying Zhu, LiHua Li, ChangRen Zhou. Processing of nanocrystalline hydroxyapatite particles via reverse microemulsions // Journal of Materials Science. - 2008. Vol. 43, iss. 1. - P. 384-389. - DOI: 10.1007/s10853-007-2182-9.

5. Rui-xue Sun, Yu-peng Lu. Fabrication and characterization of porous hydroxyapatite microspheres by spray-drying method // Frontiers of Materials Science in China. - 2008 - Vol. 2, iss. 1. P. 95-98. - DOI: 10.1007/s11706-008-0017-5.

6. Effect of $\mathrm{Si}$ and $\mathrm{Fe}$ doping on calcium phosphate glass fibre reinforced polycaprolactone bone analogous composites / M. S. Mohammadi, I. Ahmed, N. Muja, S. Almeida, C. D. Rudd, M. N. Bureau, S. N. Nazhat // Acta Biomaterialia. - 2012. - Vol. 8, iss. 4. - P. 1616-1626. DOI: $10.1016 /$ j.actbio.2011.12.030.

7. Nanocrystalline Hydroxyapatite Ceramics Produced by Low-Temperature Sintering after High-Pressure Treatment / A. S. Fomin, S. M. Barinov, Ievlev V. M., V. V. Smirnov, B. P. Mikhailov, E. K. Belonogov, N. A. Drozdova // Doklady Chemistry. - 2008. - Vol. 418, iss. 1. - P. 22-25. - DOI: 10.1134/S0012500808010084.

8. Wopenka Brigitte, Pasteris Jill D. A mineralogical perspective on the apatite in bone // Materials Science and Engineering: C. - 2005. - Vol. 25, iss. 2. - P. 131-143. DOI: $10.1016 /$ j.msec.2005.01.008.

9. Nanocrystalline hydroxyapatite for bone repair: an animal study / A. Brandt, S. Henning, G. Michler, W. Hein, A. Bernstein, M. Schulz // Journal of Materials Science: Materials in Medicine. - 2010. - Vol. 21, iss 1. - P. 283-294. - DOI: 10.1007/s10856-009-3859-1.

10. Tretyakov Yu. D. Development of inorganic chemistry as a fundamental for the design of new generations of functional materials // Russian Chemical Reviews. - 2004. - Vol. 73. P. 831-846. - DOI: 10.1070/RC2004v073n09ABEH000914.

11. Shepherd Jennifer H, Shepherd David V., Best Serena M. Substituted hydroxyapatites for bone repair // Journal of Materials Science: Materials in Medicine. - 2012. - Vol. 23, iss. 10. P. 2335-2347. - DOI: 10.1007/s10856-012-4598-2.

12. Changes of Surface Composition and Morphology after Incorporation of Ions into Biomimetic Apatite Coatings / Wei Xia, Carl Lindahl, Cecilia Persson, Peter Thomsen, J ukka Lausmaa, Håkan Engqvist // Journal of Biomaterials and Nanobiotechnology. - 2010. Vol. 1, no. 1. - P. 7-16. - DOI: 10.4236/jbnb.2010.11002.

13. Dorozhkin S. V. Biocomposites and hybrid biomaterials based on calcium orthophosphates // Biomatter. - 2011. - Vol. 1, iss 1. - P. 3-56. - DOI: 10.4161/biom.1.1.16782. 
14. Bohner M. Resorbable biomaterials as bone graft substitutes // Materialstoday. - 2010. Vol. 13, iss. 1-2. - P. 24-30. - DOI: 10.1016/S1369-7021(10)70014-6.

15. Driessens F. C. M., Wolke J. G. C., Jansen J. A. A new theoretical approach to calcium phosphates, aqueous solutions and bone remodeling // Journal of the Australian Ceramic Society. 2012. - Vol. 48, iss. 2. - P. 144-149.

16. Noor Zairin. Nanohydroxyapatite Application to Osteoporosis Management // Journal of Osteoporosis. - 2013. - Vol. 2013. - P. 1-6. - DOI: 10.1155/2013/679025.

17. Effect of ammonium carbonate on formation of calcium-deficient hydroxyapatite through double-step hydrothermal processing / S. Prakash Parthiban, Yong Kim, Koichi Kikuta, Chikara Ohtsuki // Journal of Materials Science: Materials in Medicine. - 2011. - Vol. 22, iss. 2. P. 209-216. - DOI: 10.1007/s10856-010-4201-7.

18. Synthesis and physicochemical characterization of nanocrystalline chitosan-containing calcium carbonate apatites / Zh. A. Ezhova, E. M. Koval, N. A. Zakharov, V. T. Kalinnikov // Russian Journal of Inorganic Chemistry. - 2011. - Vol. 56, iss. 6. - P. 841-846. DOI: $10.1134 / \mathrm{S} 0036023611060076$.

19. Barinov S. M. Calcium phosphate-based ceramic and composite materials for medicine // Russian Chemical Reviews. - 2010. - Vol. 79, iss. 1. - P. 13-29. DOI: 10.1070/RC2010v079n01ABEH004098.

20. Shepherd Jennifer H., Shepherd David V., Best Serena M. Substituted hydroxyapatites for bone repair // Journal of Materials Science: Materials in Medicine. - 2012. - Vol. 23, iss. 10. P. 2335-2347. - DOI: 10.1007/s10856-012-4598-2.

21. Koroleva L. F. Doped Nanocrystalline Calcium Carbonate Phosphates // Inorganic Materials. - 2010. - Vol. 46, iss. 4. - P. 405-411. - DOI: 10.1134/S0020168510040151.

22. Koroleva L. F., Larionov L. P., Gorbunova N. P. Doped calcium carbonate-phosphate-based biomaterial for active osteogenesis. Chapter 5. // Osteogenesis / ed. by Yunfeng Lin. - Croatia : InTech Publ., 2012. - ISBN 978-953-51-0030-0. - DOI: 10.5772/34119.

23. Koroleva L. F., Larionov L. P., Gorbunova N. P. Biomaterial based on doped calcium carbonate-phosphate for Active Osteogenesis // Journal of Biomaterials \& Nanobiotechnology. - 2012. - Vol. 3, iss. 2. - P. 226-237. - DOI: 10.4236/jbnb.2012.32028.

24. Koroleva L. F., Cherednichenko N. V., Dobrinskaya M. N. Doped Nanocrystalline Calcium Carbonate-Phosphate Biomaterial with Transdermal Activity for Osteogenesis. Chapter 14 // Nanotechnology. Biomaterials. Vol. 11/ ed. by Naveen Kumar Shishir, Navani Sinh. - USA-India : STUDIUM PRESS LLC, 2014. - ISBN 1-626990-11-5.

25. Koroleva L. F. An oscillating mechanism in the synthesis of doped nanocrystalline calcium carbonate phosphates // Nanotechnologies in Russia. - 2010. - Vol. 5, iss. 9-10. P. 635-640. ISSN 1995-0780.

26. Development of new biologically active material for bone reconstruction and evaluation of its application security / L. P. Larionov, L. F. Koroleva, E. F. Gaysina, M. N. Dobrinskaya // Biomeditsina. - 2011. - No. 4. - P. 101-103. (In Russian).

27. Principles of demineralization: Modern strategies for the isolation of organic frameworks Part II. Decalcification / Hermann Ehrlich, Petros G. Koutsoukos, Konstantinos D. Demadis, Oleg S. Pokrovsky // Micron. - 2009. - Vol. 40, iss. 2. - P. 169-193. DOI:10.1016/j.micron.2008.06.004.

28. Synthesis and physical chemical research of calcium carbonate-hydroxyapatite of type A / G. V. Rodicheva, V. P. Orlovsky, V. P. Privalov, S. M. Barinov, F. S. Pustikelli, S. Oskarson // Russian Journal Inorganic Chemistry. - 2001. - Vol. 46, iss. 11. - P. 1798-1802.

29. Lafon J. P., Champion E., Bernache-Assolant D. Processing of AB-type carbonated hydroxyapatite $\mathrm{Ca}_{10-\mathrm{x}}\left(\mathrm{PO}_{4}\right)_{6-\mathrm{x}}\left(\mathrm{CO}_{3}\right)_{\mathrm{x}}(\mathrm{OH})_{2-\mathrm{x}-2 \mathrm{y}}\left(\mathrm{CO}_{3}\right)_{\mathrm{y}}$ ceramics with controlled composition // Journal of the European Ceramic Society. - 2008. - Vol. 28, iss. 1. - P. 139-147. DOI: 10.1016/j.jeurceramsoc.2007.06.009. 
open-access journal

30. Release of DL- leucine by biomaterials: Apatitic calcium phosphates analogous to bone mineral / A. E. Rhilassi, M. Mourabet, H. E. Boujaady, H. Ramdane, M. Bennani-Ziatni, R. El Hamri, A. J. Taitai // Mater. Environ. Sci. - 2012. - Vol. 3, iss. 3. - P. 515-524.

31. Koroleva L. F. Nanocrystalline doped calcium carbonate-phosphates as a biomaterial for osteogenesis // Research Journal of Pharmaceutical, Biological and Chemical Sciences. - 2014. Vol.5, iss. 6. - P. 704-710.Roveri

32. Roveri Norberto, Iafisco Michele. Evolving application of biomimetic nanostructured hydroxyapatite // Nanotechnology Science and Applications. - 2010. - Vol. 3. - P. 107-125. DOI: $10.2147 /$ NSA.S9038. 